\title{
Self-medication in children and adolescents
}

\author{
Francis S. V. T. Pereira' ${ }^{1}$, Fábio Bucaretchi², Celso Stephan ${ }^{3}$, Ricardo Cordeiro ${ }^{4}$
}

\begin{abstract}
Objective: To determine the prevalence of self-medication in children and adolescents in the municipalities of Limeira and Piracicaba, state of São Paulo, and to correlate results with sociodemographic indicators and with the use of health care services (public or private).
\end{abstract}

Methods: Descriptive population-based study of a simple random sample from the two municipalities, comprised of 772 inhabitants from 85 urban census sectors selected through cluster sampling. Inclusion criteria: age $\leq 18$ years; interview with one parent/tutor; consumption of at least one drug in the previous 15 days. Subjects were divided into two study groups according to their pattern of drug use: self-medication (lay advice) and medical prescription. Linear association tests, descriptive analysis of variables and multiple logistic regression tests were carried out to analyze data.

Results: The prevalence of self-medication was $56.6 \%$. Mothers (51\%) and drugstore employees (20.1\%) were most frequently responsible for self-medication. The main groups of self-prescribed drugs were: analgesic/antipyretic and non-hormonal anti-inflammatory drugs (52.9\%); drugs acting on the respiratory tract (15.4\%) and gastrointestinal drugs $(9.6 \%)$; and systemic antibiotics $(8.6 \%)$. The situation that most commonly motivated self-medication were respiratory diseases $(17.2 \%)$, fever $(15 \%)$, and headache $(14 \%)$. Subjects in the age group of $7-18$ years (odds ratio $=2.81$ ) and public health care users (odds ratio $=1.52$ ) showed increased risk for self-medication.

Conclusions: The prevalence of self-medication in children and adolescents was high, which reinforces the need for public health interventions aiming at preventing this practice.

J Pediatr (Rio J). 2007;83(5):453-458: Children, adolescents, drugs, self-medication, pharmacoepidemiology.

\section{Introduction}

Self-medication includes several forms through which the individual him/herself or the ones responsible for him/her decide, without medical evaluation, which drug they will use and in which way for the symptomatic relief and "cure" of a condition; it involves sharing drugs with other members of the family and social group, using leftovers from previous prescriptions or disrespecting the medical prescription either by prolonging or interrupting the dosage and the administration period prescribed. ${ }^{1,2}$
The consumption of pharmaceuticals can be considered an indirect indicator of the quality of health care services, ${ }^{2-6}$ and children and adolescents are strongly susceptible to the irrational use of drugs with and without medical control. ${ }^{7-12}$ Economic, political and cultural factors have contributed to the growth and spread of self-medication worlwide. ${ }^{13-21}$ These factors are related with aspects such as the great availability of products in the current days; the state of health that a pharmaceutical agent may represent; irresponsible publicity;

1. Mestre. Departamento de Farmacologia, Faculdade de Ciências Médicas (FCM), Universidade Estadual de Campinas (UNICAMP), Campinas, SP, Brazil. Doutoranda, Programa de Pós-Graduação em Saúde da Criança e do Adolescente, Departamento de Pediatria, FCM, UNICAMP, Campinas, SP, Brazil.

2. Doutor. Professor assistente, Departamento de Pediatria, FCM, UNICAMP, Campinas, SP, Brazil. Coordenador, Centro de Controle de Intoxicações, FCM, UNICAMP, Campinas, SP, Brazil.

3. Mestre, Universidade Estadual Paulista (UNESP), São Paulo, SP, Brazil. Doutorando, Programa de Pós-Graduação em Saúde Coletiva. Colaborador voluntário, Laboratório de Análise Espacial de Dados Epidemiológicos (EPIGEO), Departamento de Medicina Preventiva e Social, FCM, UNICAMP, Campinas, SP, Brazil.

4. Professor associado, Departamento de Medicina Preventiva e Social, FCM, UNICAMP, Campinas, SP, Brazil. Coordenador, Laboratório de Análise Espacial de Dados Epidemiológicos (EPIGEO), Departamento de Medicina Preventiva e Social, FCM, UNICAMP, Campinas, SP, Brazil.

This study is part of the doctoral dissertation by Francis S. V. T. Pereira, advised by Dr. Fábio Bucaretchi. Prof. Celso Stephan and Prof. Dr. Ricardo Cordeiro assisted the statistical analyses.

Suggested citation: Pereira FS, Bucaretchi F, Stephan C, Cordeiro R. Self-medication in children and adolescents. J Pediatr (Rio J). 2007;83(5):453-458.

Manuscript received Mar 30 2007, accepted for publication July 112007.

doi 10.2223/JPED.1703 
pressure to convert prescription-only drugs into over-thecounter drugs; quality of health care; difficult access to health care services in poor countries. ${ }^{2-6,13-21}$

Studies focusing on the use of pharmaceuticals in children and adolescents are rare, mainly in developing countries. ${ }^{7-11}$ Moreover, the prevalence of self-medication in Brazilian children has been assessed only by a few nonsystematic studies, which found results from 7.1 to $53.2 \%$ for different age groups. ${ }^{7,9-11}$ Therefore, we carried out an epidemiologic, population-based study with children and adolescents aged $\leq 18$ years from two medium-sized countryside municipalities from the state of São Paulo (Limeira and Piracicaba). The objective of the study was to identify the prevalence and the pattern of medication use in self-medicated individuals and age-matched subjects following medical prescriptions; the main groups and types of drugs employed in self-medication were identified, as well as some variables that may influence their use.

\section{Methods}

This descriptive, cross-sectional, exploratory, populationbased study was carried out from September 8, 2003 to September 7, 2004. Inclusion criteria were: age $\leq 18$ years; interview with one parent/tutor; consumption of at least one drug in the 15 days preceding the interview. Homes were excluded if one of the following conditions was met: parents/ tutors were not present at the time of the interview or refused to participate; the home was a commercial establishment; there were no residents aged $\leq 18$ years; no drug had been consumed in the 15 days preceding the interview.

By estimating a rate of $41.4 \%$ of self-medication in children (Gomes), ${ }^{11}$ our sample was defined based on 372 home interviews for the urban areas of each municipality, at a total of 744 cases (acceptable error of 5\%). These estimates were based on the demographic census (Instituto Brasileiro de Geografia e Estatística - IBGE), year 2000, which shows an approximate total of 80,951 and 101,800 individuals aged $\leq$ 18 years in Limeira and Piracicaba, respectively (ESTATCART 1.2, IBGE, Rio de Janeiro, RJ, Brazil, 2002).

Homes were selected through simple random cluster sampling, using the urban census sectors defined by IBGE as reference (327 sectors in Limeira and 482 in Piracicaba). According to the population of children and adolescents estimated for each sector, we found that 60 sectors from the two municipalities would be enough to compose the sample. However, we decided to select a higher number of sectors (200), so as to assure that we would find the minimum number of individuals required, mainly in central sectors (commercial establishments) and old neighborhoods inhabited by elderlies. For each sector drawn, we printed an IBGE map (ESTATCART 1.2, IBGE, 2002) to help the interviewer find the points of interest, following a pre-established systematic sequence for the selection of homes.
Data were collected by six interviewers previously trained in a pilot study carried out to validate the collection of data. A structured questionnaire with open- and closed-ended questions was employed. In homes with more than one child, only one interview was carried out, and the individual was selected by lot, using a table of random numbers.

The dependent variable was the use of pharmaceuticals, and subjects were divided into two study groups: selfmedication, i.e., when the use of drugs resulted from lay advice; and medical prescription, i.e., when the use of drugs resulted from a medical visit and prescription. Drugs were classified in groups and subgroups according to the last version of the Anatomical-Therapeutic-Chemical (ATC) Classification System of the World Health Organization. ${ }^{22}$

Two groups of exploratory variables were considered: sociodemographic variables and the use of health care services - public or private (health care plans/private medical visits). The following socioeconomic indicators were considered: occupation of parents/tutors (employed or unemployed/retired); family income (number of minimum wages); and the criteria of Associação Brasileira de Anunciantes (Brazilian Association of Advertisers) and Associação Brasileira de Pesquisas de Institutos de Mercado (Brazilian Association of Market Research Institutes) (ABA/ABIPEME), which are considered to be an indicator of consumption potential and consumption habits. ${ }^{23}$

For the analysis of data, a descriptive analysis of the dependent and of the exploratory variables was first carried out, followed by association tests (Person's chi-square). Variables showing a correlation with self-medication $(p<0.2$ in the bivariate analysis) were further analyzed in a multiple logistic regression model; odds ratios (OR) and the respective confidence intervals were calculated. Mann-Whitney's $U$ test was applied to analyze the difference in the distribution of age information in the two study groups. Analyses were processed using Epi-Info version 6.04 (CDC/WHO, Atlanta, GE, USA), SPSS for Windows version 7.5 (SPSS Inc., Chicago, IL, USA), and $R$ version 2.4.1. ${ }^{24}$

The study protocol was approved by the Research Ethics Committee of the Faculty of Medical Sciences at Universidade Estadual de Campinas (UNICAMP) (process no. 510/2002). Participants were informed of the objective of the study; an informed consent form was signed by the parent/tutor.

\section{Results}

A total of 1,765 homes were visited so as to reach the total number of valid cases for the study ( $n=772$, from 85 census sectors; Limeira, 53.6\%; Piracicaba, 46.4\%). Valid interviews followed a similar distribution pattern in the 12 months of study, both in Limeira (36.4 \pm 3.7 interviews/month, 32-46 interviews) and in Piracicaba (28 \pm 3.5 interviews/month, 24-38 interviews). Mean age was $9.6 \pm 5.2$ years ( 29 days -18 years) in self-medicated individuals and $6.6 \pm 4.9$ years ( 4 
days-18 years) in those using drugs according to medical prescription.

Considering the use of drugs in the 15 days prior to the interview, the prevalence of self-medication was $56.6 \%$ ( $\mathrm{n} / \mathrm{N}$ $=437 / 772)$, and there was no statistical difference between the two municipalities (Limeira, $\mathrm{n} / \mathrm{N}=226 / 414$; Piracicaba, $\mathrm{n} / \mathrm{N}=211 / 358$; chi-square test, $\mathrm{p}=0.25)$. The majority of participants lived in masonry homes (98.4\%) and had access to sewage system (98.1\%), public water supply (98.8\%), and public garbage collection (98.8\%).

The bivariate analysis revealed that the use of selfmedication was significantly more frequent $(p<0.05)$ in older age groups and in groups that used public health care services (Figure 1 and Table 1). Sex and socioeconomic conditions did not show a significant association (Table 1 ). Table 2 shows the results of the multivariate analysis: individuals in age group $7-18$ years $(O R=2.81)$ and public health care users $(O R=1.52)$ showed an increased risk for self-medication.

The health conditions that most frequently motivated selfmedication were cough, colds, flus, nasal congestion or bronchospasm (17.2\%); fever (15\%); headache (14\%); diarrhea, "poor digestion" and abdominal pain ( $9 \%)$. In self-medication, $51 \%$ of the drugs were indicated by mothers, $7.8 \%$ by fathers, and $20.1 \%$ by drugstore employees; $15.3 \%$ resulted from the use of old medical prescriptions originally given to the child or to other family members and $1.8 \%$ were influenced by the media.

The number of medicines consumed was proportionally higher in the prescribed population (Table 3 ). The frequency of use of analgesic/antipyretic and non-hormonal antiinflammatory drugs was observed to be significantly higher in self-medicated individuals, while systemic antibiotics, vitamins and antianemic drugs, as well as systemic histamine $\mathrm{H} 1$ receptor antagonists were significantly more consumed by the groups receiving recent medical prescriptions (Table 3 ). In relation to active principles, the high frequency of the use of dipyrone and diclofenac in self-medicated individuals, and of amoxicillin, dipyrone and diclofenac in prescribed individuals (Table 3) should be emphasized.

\section{Discussion}

The results of the present study confirm that the prevalence of self-medication in children and adolescents is a real and frequent practice, independently on socioeconomic data; this finding is in accordance with previous reports by other authors. ${ }^{7-11,13,25}$

The lower frequency of self-medication observed in age group $<7$ years should be noted. A study carried out in Holland to analyze the consumption of pharmaceuticals in individuals $<17$ years showed that the prevalence of consumption is significantly higher in children $<1$ year of age, followed by the 2-5 years' age group. ${ }^{26} \mathrm{~A}$ similar result was found in a Brazilian study on the use of pharmaceuticals in public day care

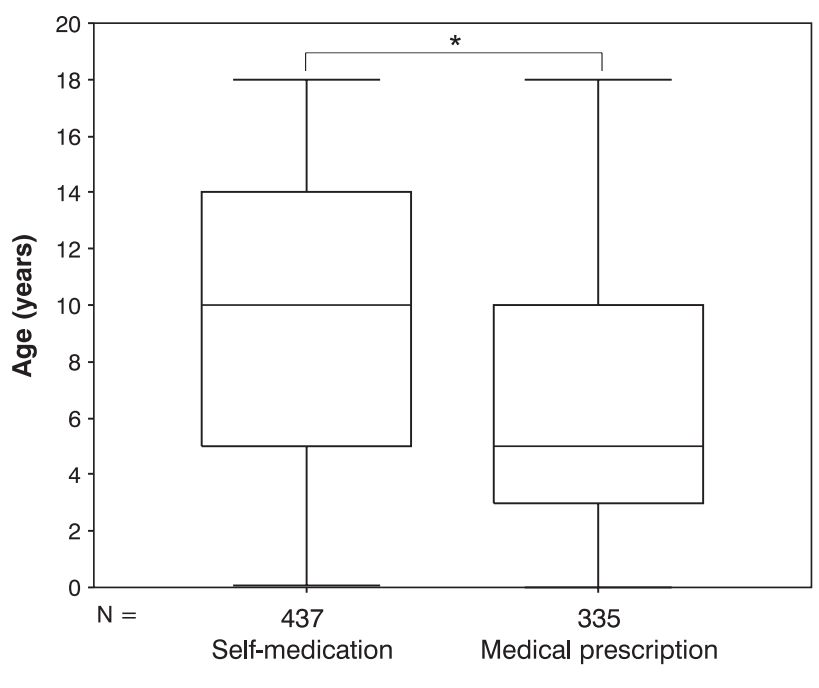

$* \mathrm{p}<0.001$ (Mann-Whitney's U test).

Figure 1 - Graph representing the groups of children and adolescents receiving self-prescribed and medicallyprescribed drugs in the 15 days preceding home interview, according to age. Data are presented by box and whisker plots; in each box plot, the lower, intermediate and upper horizontal lines represent the 1st quartile (percentile 25), the median (percentile 50), and the 3rd quartile (percentile 75), respectively. The lower and upper limits of the vertical lines represent the lowest and highest values observed, respectively.

centers from a specific region of the city of São Paulo (age group 0-7 years). These data suggest that although the prevalence of consumption of medically-prescribed drugs is higher in infants and preschool-aged children, the lower the age group, the more parents/tutors hesitate to accept lay advice on the use of pharmaceuticals.

In accordance with previous studies, $9,11,13,25$ we observed a predominance of mothers administering nonprescribed drugs to children. This finding has been attributed to the social roles that are traditionally reserved to mothers, including the role of promoting health in the family. ${ }^{9,11,13,25}$ In $20.1 \%$ of the cases, advice for self-medication was given at the drugstore, a common fact in Brazil and other countries. $3,4,6,11,19-21,25,27$ In our study, according to the interviewees' opinion, only $1.8 \%$ of the cases of selfmedication were influenced by the media, similarly to what has been described for another medium-sized municipality in southern Brazil (2.7\%). ${ }^{25}$ However, we believe that these results underestimate the real effect of the media on selfmedication indices. ${ }^{14,15}$

Analgesic/antipyretic and non-hormonal antiinflammatory agents were the most commonly self-prescribed drugs, which indicates that self-medication is usually associated with the symptomatic treatment of pain. ${ }^{2-3,6-9,11,13,25,27,28}$ Although pharmaceuticals such as acetaminophen and dipyrone are relatively safe analgesic and antipyretic agents for use in children, provided adequate 
Table 1 - Bivariate analysis of sociodemographic variables and data on access to health care services considering use of self-prescribed or medicallyprescribed drugs (dependent variable) in the 15 days preceding home interview - Limeira and Piracicaba (SP), Brazil

\begin{tabular}{|c|c|c|c|}
\hline Population characteristics & $\begin{array}{c}\text { Self-medication } \\
(n=437) \%\end{array}$ & $\begin{array}{c}\text { Medical prescription } \\
(n=335) \%\end{array}$ & p* \\
\hline \multicolumn{4}{|l|}{ Age group (years) } \\
\hline$<2$ & 6.4 & 13.8 & \\
\hline $2-7$ & 28.1 & 45.8 & \\
\hline $7-14$ & 35.9 & 26.0 & \\
\hline $14-18$ & 29.5 & 14.4 & $<0.001$ \\
\hline \multicolumn{4}{|l|}{ Sex } \\
\hline Female & 49.0 & 51.9 & \\
\hline Male & 51.0 & 48.1 & 0.41 \\
\hline \multicolumn{4}{|c|}{ Family income (no. of minimum wages) } \\
\hline$<3$ & 39.3 & 39.4 & \\
\hline 3-5 & 30.2 & 29.0 & \\
\hline $5-10$ & 16.7 & 20.3 & \\
\hline$>10$ & 10.8 & 9.0 & \\
\hline Did not inform/no income & 3.0 & 2.4 & 0.68 \\
\hline \multicolumn{4}{|l|}{ Parent/tutor occupation } \\
\hline Employed & 76.4 & 77.0 & \\
\hline Not employed/retired & 19.9 & 19.7 & \\
\hline Did not inform & 3.7 & 3.3 & 0.96 \\
\hline \multicolumn{4}{|c|}{ Classification of consumption habits (ABA/ABIPEME) } \\
\hline $\mathrm{E}$ & 7.3 & 7.2 & \\
\hline $\mathrm{D}$ & 27.5 & 22.4 & \\
\hline $\mathrm{C}$ & 43.2 & 48.1 & \\
\hline B & 20.6 & 21.2 & \\
\hline A & 1.4 & 1.2 & 0.56 \\
\hline \multicolumn{4}{|l|}{ Access to health care services } \\
\hline Public & 58.1 & 47.8 & \\
\hline Private & 41.9 & 52.2 & 0.005 \\
\hline
\end{tabular}

* Chi-square test.

ABA/ABIPEME = Associação Brasileira de Anunciantes/Associação Brasileira de Pesquisas de Instituto de Mercado.

doses are respected, the chronic and abusive use of these substances should be prohibited. ${ }^{12}$ On the other hand, considering inherent risks ${ }^{12}$ associated with non-hormonal antiinflammatory drugs, the excessive use of such agents as

Table 2 - Variables associated with use of self-medication in the 15 days preceding home interview in the multivariate analysis - Limeira and Piracicaba (SP), Brazil

\begin{tabular}{ccc}
\hline Variables & Odds ratio & 95\% confidence interval \\
\hline \multicolumn{3}{l}{ Age group (years) } \\
$<7$ & 1.00 & - \\
$7-18$ & 2.81 & $2.09-3.77$ \\
Access to health care services & \\
Public & 1.52 & $1.14-2.02$ \\
Private & 1.00 & - \\
\end{tabular}

observed in our study, both self-prescribed (11.2\%) and medically-prescribed (7.2\%), is unacceptable, especially when compared to countries such as Holland, where the consumption of these substances is much lower (2\%). ${ }^{26}$ Acetylsalicylic acid was the fourth most frequently self-prescribed active principle, and it is also associated with some risks, such as the risk of development of Reye's syndrome in a 2-year old child with varicella, as previously reported. ${ }^{12}$ Furthermore, since a great part of the complaints treated with selfmedication resulted from respiratory conditions, atopic individuals consuming acetylsalicylic acid or other nonhormonal anti-inflammatory drugs would also be at higher risk for worsening the clinical signs of allergic manifestations. ${ }^{12}$

In the majority of cases, the systemic antibiotics used in self-medication were available from old, partially used prescriptions, and several were expired. Temporary use of antibiotics may cause adverse effects and the development of bacterial resistance ${ }^{9,12}$ in addition, the selection of drugs was 
Table 3 - Pharmaceuticals most commonly used according to groups and subgroups of the Anatomical-Therapeutic-Chemical Classification (World Health Organization), considering pattern of use in the 15 days preceding home interview - Limeira and Piracicaba (SP), Brazil

\begin{tabular}{|c|c|c|c|c|}
\hline Pharmaceuticals & ATC code & $\begin{array}{l}\text { Self-medication } \\
(n=456)^{+} \%\end{array}$ & $\begin{array}{l}\text { Medical prescription } \\
(n=460)^{\neq} \%\end{array}$ & p* \\
\hline Analgesic/antipyretic agents & N02 & 41.7 & 12.6 & $<0.001$ \\
\hline Dipyrone & N02BB02 & 27.4 & 9.6 & \\
\hline Acetaminophen & N02BE01 & 6.8 & 2.6 & \\
\hline Acetylsalicylic acid & N02BA01 & 4.8 & 2.0 & \\
\hline Non-hormonal anti-inflammatory & M01A & 11.2 & 7.2 & 0.047 \\
\hline Diclofenac & M01AB05 & 8.8 & 5.7 & \\
\hline Nimesulide & M01AX17 & 1.8 & 1.3 & \\
\hline Action on the respiratory tract & $\mathrm{R}$ & 15.4 & 18.7 & 0.17 \\
\hline Antiflu and anticough drugs & R05 & 11.6 & 11.5 & \\
\hline$\beta_{2}$-adrenergic agonists & R03AC & 0.4 & 4.1 & \\
\hline Systemic antibiotics & J01 & 8.6 & 17.0 & $<0.001$ \\
\hline Amoxicillin & J01CA04 & 3.7 & 10.9 & \\
\hline Action on the gastrointestinal tract & A & 9.6 & 6.3 & 0.06 \\
\hline Antispasmodics & A03 & 3.5 & 0.9 & \\
\hline Dimethicone & $\mathrm{A} 03 \mathrm{~A} \times 13$ & 3.9 & 3.4 & \\
\hline Vitamins/antianemic agents & A11/ B03 & 3.1 & 8.3 & $<0.001$ \\
\hline Antiparasitic/antihelminthic agents & P01/ P02 & 2.4 & 3.7 & 0.26 \\
\hline Systemic histamine $\mathrm{H} 1$ antagonists & R06 & 0.7 & 5.4 & $<0.001$ \\
\hline
\end{tabular}

based on old medical prescriptions, possibly aimed at treating different diseases.

Although the association between pattern of use of health care services and self-medication is controversial, ${ }^{27}$ we observed that individuals with access to the public system presented an increased risk for practicing self-medication. However, further studies are necessary to evaluate whether this behavior reflects a difference in the quality of care when comparing public and private health care services in the municipalities of Limeira and Piracicaba.

Several efforts were made in the sense of eliminating any bias from analysis of results in the present study. However, some limitations should be taken into account. Although some authors consider 24 hours to be the ideal time period for obtaining information on the use of pharmaceuticals, ${ }^{10}$ the period of 2-14 days has also been employed in studies with children, ${ }^{7,13}$ and up to 90 days have been used in adults. ${ }^{25}$ In relation to the total number of valid cases, it is possible that our sample is not completely representative of the proportion of individuals in each age group, since the population was selected through simple random sampling. Thus, as in any study of this size, definitive conclusions about self-medication in the age groups studied should be avoided.

The results herein presented reinforce the need for a public policy aiming at defining health promotion interventions and strategies to prevent self-medication, which may pose risks to users and to the community as a whole.

\section{Acknowledgements}

We are grateful to Fundo de Apoio à Pesquisa da Universidade Metodista de Piracicaba (FAP/UNIMEP, 2003-2004), for the partial financial support to this study; to the interviewers (Juliane Ananias, Viviane Souza, Maísa Gui, Maria Teresa Mayer, Caroline Sousa, and Aline dos Santos) and to the families that participated in the study.

\section{References}

1. Paulo LG, Zanini AC. Automedicação no Brasil. Rev Ass Med Bras. 1988;34:69-75.

2. Arrais PS, Coelho HL, Batista MC, Carvalho ML, Righi RE, Arnau JM. Perfil da automedicação no Brasil. Rev Saude Publica. 1997;31:71-7.

3. Multicenter study on self-medication and self-prescription in six Latin American countries. Drug Utilization Research Group, Latin America. Clin Pharmacol Ther. 1997;61:488-93.

4. Laporte JR. Principios de epidemiología del medicamento. 2 ed. Barcelona: Masson; 1993.

5. Dukes MN. Drug utilization studies. Methods and uses. Introduction. WHO Reg Publ Eur Ser. 1993;45:1-4. 
6. Carvalho MF, Pascom AR, Souza-Junior PR, Damacena GN, Szwarcwald CL. Utilization of medicines by the Brazilian population, 2003. Cad Saude Publica. 2005;21 Suppl:100-8.

7. Béria JU, Victora CG, Barros FC, Teixeira AB, Lombardi C. Epidemiologia do consumo de medicamentos em crianças de centro urbano da região sul do Brasil. Rev Saude Publica. 1993;27:95-104.

8. Urbano B, Magro R, Masip M, Vacas R. Automedicación en pediatría general. Atención Primaria. 1994;13:313-6.

9. Bricks LF, Leone C. Utilização de medicamentos por crianças atendidas em creches. Rev Saude Publica. 1996;30:527-35.

10. Weiderpass E, Béria JU, Barros FC, Victoria CG, Tomasi E, Halpern R. Epidemiologia do consumo de medicamentos no primeiro trimestre de vida em centro urbano do sul do Brasil. Rev Saude Publica. 1998;32:335-44.

11. Gomes MFS. Estudo da automedicação infantil em uma região administrativa no município do Rio de Janeiro [dissertação]. Rio de Janeiro: Universidade Federal do Rio de Janeiro, 2000.

12. Bricks LF. Uso judicioso de medicamentos em crianças. J Pediatr (Rio J). 2003;79 Suppl 1:S107-14.

13. da Silva $\mathrm{CH}$, Giugliani ER. Consumo de medicamentos em adolescentes escolares: uma preocupação. J Pediatr (Rio J). 2004; $80: 326-32$.

14. Johnson RE, Pope CR. Health status and social factors in nonprescribed drug use. Med Care. 1983;21:225-33.

15. Lefévre F. A função simbólica dos medicamentos. Rev Saude Publica. 1983;15:500-3.

16. Fabricant S, Hirschhorn N. Deranged distribution, perverse prescription, unprotected use: the irrationality of pharmaceuticals in the developing world. Health Policy Plan. 1987;2:204-13.

17. Segall A. A community survey of self-medication activities. Med Care. 1990;28:301-10.

18. Laporte JR. Automedicación: la información de los usuarios aumenta al mismo tiempo que el consumo? Med Clin (Barc). 1997; 109:795-6.
19. Kennedy JG. Over the counter drugs. BMJ. 1996;312:593-4.

20. Bradley C, Blenkinsopp A. Over the counter drugs: the future of self medication. BMJ. 1996;312: 835-7.

21. Lowe NK, Ryan-Wenger NM. Over-the-counter medications and self-care. Nurse Pract. 1999;24:34-44.

22. WHO Collaborating Centre for Drug Statistic Methodology [banco de dados na Internet]. ATC/DDD Index 2007. Disponível em: http://www.whocc.no/atcddd/. Access: 28/06/2007.

23. Mattar FN. Análise crítica dos estudos de estratificação socioeconômica da ABA-Abipeme. Rev Adm. 1995;30:57-74.

24. The R Project for Statistical Computing [site na Internet]. Disponível em: http://www.r-project.org/ Access: 20/06/2007.

25. Vilarino JF, Soares IC, Silveira CM, Rödel AP, Bortoli R, Lemos RR. Perfil da automedicação em município do Sul do Brasil. Rev Saude Publica. 1998;32:43-9.

26. Schirm E, van den Berg $P$, Gebben $H$, Sauer $P$, De Jong-van den Berg L. Drug use of children in the community assessed through pharmacy dispensing data. Br J Clin Pharmacol. 2000;50:473-8.

27. Loyola Filho AI, Uchoa E, Guerra HL, Firmo JO, Lima-Costa MF. Prevalência e fatores associados à automedicação: resultados do Projeto Bambuí. Rev Saude Publica. 2002;36:55-62.

28. Martins AP, Miranda Ada C, Mendes Z, Soares MA, Ferreira P, Nogueira A. Self-medication in a Portuguese urban population: a prevalence study. Pharmacoepidemiol Drug Saf. 2002;11:40914.

Correspondence:

Fábio Bucaretchi

Depto. de Pediatria e Centro de Controle de Intoxicações,

FCM, HC-UNICAMP

Caixa Postal, 6111

CEP 13083-970 - Campinas, SP - Brazil

Tel.: +55 (19) 3521.7861 , +55 (19) 3521.7437

Fax: +55 (19) 3521.8873

E-mail: bucaret@fcm.unicamp.br 